\title{
AN OVERVIEW OF THE TALL FESCUE ENDOPHYTE PROBLEM IN THE U.SA.
}

\author{
J.P. MUELLER
}

North Carolina State University.

\section{Abstract}

Tall fescue is the most important cool-season pasture species in the transition zone of the southeastern U.S.A., occupying more than 10 million hectares. Forage quality indices such as crude protein, in vitro digestibility etc. indicate that tall fescue should be capable of stimulating high animal performance. Nevertheless since its widespread introduction in the early 1950's, tall fescue has been associated with a myriad of animal production problems. Recently researchers have been able to associate poor animal performance with an endophytic fungus present in the plant tissue of tall fescue. The history and current situation in the U.S. with respect to the endophyte of tall fescue and its influence on economic animal production are discussed.

K eywords: Tall fescue toxicity, endophyte, Summer Syndrome, ocremonium coenophialum.

\section{INTRODUCTION}

In the transition zone which separates southern and northern regions of the United States, there are over 10 million hectares of tall fescue (Festuca arundinacea Schreb.). This cool-season perennial grass is adapted to a wide range of soil and climatic conditions, is easily established, will withstand abusive grazing management, and is a good seed producer. Whether grown in mixture with clover (Trifolium repens or $T$. protense) or in pure stand with $\mathrm{N}$ fertilisation, tall fescue is capable of producing high annual yields of dry matter (10 to $14 \mathrm{t} / \mathrm{ha}$ ). Although growth is severely reduced during mid-summer, fescue may provide 150 to 240 days of grazing yearly.

Chemical and biological estimates of forage quality such as fibre (NDF, ADF), crude protein, and in uitro digestibility seem to suggest that tall fescue is potentially very high in quality. Nevertheless numerous animal production problems have been reported when animals graze tall fescue pastures (Blaser et al. 1956; Bush and Buckner 1973).

\section{THE DEVELOPMENT OF TALL FESCUE AS AN IMPORTANT U.S. PASTURE SPECIES}

In 1931 Dr E.N. Fergus of the University of Kentucky was summoned to the farm of W.M. Suiter in Menifee County, Kentucky to observe a vigorous grass that was growing there. Dr Fergus was impressed with the grass and obtained several hundred grams of seed which he planted on the University Experiment Station in 1932 Subsequent plantings were made at different sites and in 1939 a limited amount of seed was distributed to interested farmers for on-farm trials. Since the original field on the Suiter farm had been in this grass for many years there was little doubt about its climatic adaptation. It was thought that some of the grass was present when Mr Suiter bought the farm in 1887 . The seed for the original planting was thought to have come from a Virginia seedsman.

In 1942 "Kentucky 31" (KY 31) tall fescue was released (Fergus and Buckner 1972). This new grass was rapidly accepted by the farmers of the southeastern U.S.A. During the late 1940's and the decade of the 1950's millions of hectares were established. Today, Kentucky 31 tall fescue is by far the predominant cultivar grown in the transition zone. Although this new grass had many agronomic advantages, its undesirable attributes soon became evident as the grass came into widespread farm use. 


\section{ANIMAL PRODUCTION PROBLEMS}

With advent of extensive on-farm use of KY 31, animal production problems were often evident. Tall fescue quickly developed a reputation with dairymen as an unpalatable grass unfit for use with milk cows. Beef producers usually recognised the problem as lack of production and occasionally as a serious malady which became known as "fescue foot". Researchers performing chemical and biological estimates of forage quality found that tall fescue compared favourably with other cool-season perennial grasses even though performance of animals grazing tall fescue was sometimes poor. Over the years various terms, each associated with one or more tall fescue related animal disorders, have come into common use (Ball 1982). What follows is an attempt to classify and define these terms.

a) Tall fescue toxicosis or tall fescue toxicity - These terms relate in a general way to disorders associated with performance, appearance and behaviour of animals grazing tall fescue, however this terminology is frequently used in reference to b) below.

b) Summers syndrome" or "Summer slump" - refers specifically to poor animal performance most commonly observed with cattle grazing tall fescue during the summer and may include any or all of the following symptoms - rough hair coat, rapid breathing, excessive salivation, nervousness, elevated body temperature, increased sensitivity to heat, i.e. animals continually seek to stand in shade or water (Robins 1983).

c) Fescue foot - a non infectious disorder in cattle resembling ergot toxicity. A gangrenous condition develops in the extremities and ultimately may result in sloughing of hooves, tail switch or ear tips. The condition usually begins with animals showing an arching back, rough hair coat and sore hooves. As lameness develops swelling and inflamation of the coronary band (area between dewclaws and hooves) becomes evident and in severe cases the hoof is eventually sloughed (usually rear hoof). Similar changes may also occur in distal end of the tail and in the ear tips (Creighton and Garner 1980).

d) Bovine fat necrosis or lipomatosis - This condition has been reported with beef cattle grazing tall fescue pastures. It is characterised by hardened or necrotic fat masses present mostly in the adipose tissue of the abdominal cavity. Cattle normally do not show symptoms until there is interference with vital body functions. Intestinal blockage and constriction and resulting digestive problems are most common (Rumsey et al. 1979).

e) Reproductive problems and agalactia - Livestock producers have frequently reported reproductive problems with animals grazing tall fescue. Lower than normal calving percentages have been attributed to tall fescue. Horsemen have reported prolonged gestation and sometimes abortions when mares grazed tall fescue pastures up until foaling (Garrett et al. 1980). Moderate to severe agalactia has been reported in both cattle and horses and is thought to be related to depression in the level of serum prolactin, the hormone believed to initiate and maintain lactation (Hurley et al. 1981).

\section{ENDOPHYTE DETECTED}

For many years researchers were in disagreement as to the cause of tall fescue. induced animal disorders. In 1973, researchers at the R.B. Russell Agricultural Research Centre in Athens, Georgia examined two herds of Angus cattle maintained on two separate sets of tall fescue pastures on the same farm. One herd exhibited severe fescue toxicity symptoms while the other herd was symptomless (Robbins 1983). From 1973 to 1976 the herds of cattle were maintained on the separate pastures while extensive testing of the pasture swards was done. In 1976 (Bacon et al. 
1977) it was discovered that $100 \%$ of the fescue samples from toxic pastures (where animals exhibited toxicity symptoms) were infested with an endophytic fungus identified as Epichloe typhina (Pers.) TUL. (later renamed Acremonium coenophialum Morgan-Jones and Gams). Pasture samples collected from paddocks where the animals remained symptomless were only $10 \%$ infested with the fungus.

\section{CHARACTERISTICS OF THE ENDOPHYTE}

Endophytic fungi in grasses have been recognised for many years (Neil 1941). However certain aspects of the tall fescue endophyte, Acremonium coenophialum, are noteworthy. The endophyte is seedborne completing its life cycle within the plant (Bacon et al. 1977, Siegel et al. 1985). Unlike some spore-producing endophytes, A. coenophialum spores have never been found on plants. This is an important feature of the fungus because it implies that disemination of the endophyte is entirely by seed; a condition easily controlled. In the seed, the fungus is found between the embryo and the aleurone layer; during germination the fungal mycelia grow into the endosperm and subsequently into the developing seedling. The fungus is concentrated in the leaf sheaths and stems and grows into the flowering tillers during reproductive growth. As flowering proceeds the fungus invades the ovules, completing its life cycle after being sequestered in the ripening seed. The endophyte's growth within the plant is entirely intercellular, never penetrating the plant cells. When plants are dormant the endophyte resides in the apical meristem until growth resumes. In storage the endophyte slowly dies as the seed ages; unless seed is stored at cold temperatures and low humidity. Storage under normal warehouse conditions for 18 to 24 months is usually sufficient to kill the endophyte (Siegel et al. 1984).

The aforementioned features of the endophyte aid the explanation of why it has been estimated that over $90 \%$ of the tall fescue pastures in the U.S. are infested with the endophyte (Siegel et al. 1985). First, it is highly likely that the original seed lot of KY 31 obtained from the Suiter farm in 1931, was infested (recent tests confirm a high level of infestation). Second, during the period when vast areas of KY 31 were being established, fresh seed was planted each year because the demand was great, precluding seed carry-over. Third, the almost exclusive use of one cultivar, KY 31 , resulted in widespread infestation.

\section{Plant}

\section{IMPORTANT RESEARCH FINDINGS}

Recently ergot alkaloids have been isolated from A. coenophialum infested tall fescue leaf blades and sheaths (Lyons and Bacon 1984). These alkaloids are not found in non-infested tall fescue and they are unrelated to the loline alkaloids previously reported to be involved in tall fescue toxicosis (Bush and Buckner 1973). These ergot alkaloids which are associated with many of the previously mentioned cattle toxicity symptoms of tall fescue toxicosis, are apparently produced by $A$. coenophialum since they have been found in the leaf blades, sheath and seed. It is assumed that ergot alkaloids distributed in the leaf blades (where no fungal tissue is found) is produced elsewhere and translocated to the blades (Lyons and Bacon 1984). Ergot alkaloids have also been isolated from the fungus in culture (Porter et al. 1979).

Although a mutually beneficial relationship has been reported between the endophyte A. loliae and the host grass Lolium perenne L. in both the U.S. (Funk et al. 1983) and New Zealand (Prestidge et al. 1982), no such relationship has been reported for tall fescue and its endophyte. The lolium endophyte apparently imparts insect resistance to the host grass. There is a need to intensify investigations of this relationship with tall fescue and A. coenophialum. 
TABLE 1: Summary of selected animal performance data comparing endophyte infested and non-infested tall fescue.

\begin{tabular}{|c|c|c|c|}
\hline $\begin{array}{l}\text { Animal Performance } \\
\text { Category }\end{array}$ & $\begin{array}{cl}\text { Percent } & \text { Increase } \\
\text { non-infested } & \text { vs infested }\end{array}$ & Animal Tyr & $\begin{array}{l}\text { pe } \\
\text { Forage }\end{array}$ \\
\hline $\begin{array}{l}\text { Average Daily Gain } \\
\text { Hoveland et. al (1980) } \\
\text { Hoveland et. al (1983) } \\
\text { Siegel et. al ( 1985) } \\
\text { Siegel et. al (1985) } \\
\text { Schmidt et. al (1981) } \\
\text { Schmidt et. al (1981) } \\
\text { King et. al (1982) }\end{array}$ & $\begin{array}{ll}-\%- \\
51 \\
66 \\
56 \text { (Apr.-Aug.) } \\
39 \text { (Nov.-Dec.) } \\
380 \\
136 \\
38\end{array}$ & $\begin{array}{l}\text { Beef steers } \\
\text { Beef steers } \\
\text { Calves } \\
\text { Calves } \\
\text { Steers } \\
\text { Steers } \\
\text { Calves }\end{array}$ & $\begin{array}{l}\text { Pasture } \\
\text { Pasture } \\
\text { Pasture } \\
\text { Pasture } \\
\text { Seed } \\
\text { Hay } \\
\text { Pasture }\end{array}$ \\
\hline $\begin{array}{l}\text { Beef Gain per Hectare } \\
\text { Hoveland et. al (1980) } \\
\text { Hoveland et. al (1983) } \\
\text { King et. al (1982) }\end{array}$ & $\begin{array}{l}26 \\
28 \\
39\end{array}$ & $\begin{array}{l}\text { Steers } \\
\text { Steers } \\
\text { Calves }\end{array}$ & $\begin{array}{l}\text { Pasture } \\
\text { Pasture } \\
\text { Pasture }\end{array}$ \\
\hline $\begin{array}{l}\text { Live Weight Gain per Animal } \\
\text { Hoveland et. al (1983) }\end{array}$ & 71 & Steers & Pasture \\
\hline $\begin{array}{l}\text { Feed Intake } \\
\text { Schmidt et. al (1981) } \\
\text { Schmidt et. al (1981) } \\
\text { Siegel et. al (1985) }\end{array}$ & $\begin{array}{r}55 \\
0 \\
20\end{array}$ & $\begin{array}{l}\text { Steers } \\
\text { Steers } \\
\text { cows }\end{array}$ & $\begin{array}{l}\text { Seed } \\
\text { Hay } \\
-1\end{array}$ \\
\hline $\begin{array}{l}\text { Milk Production } \\
\text { Siegel et. al (1985) }\end{array}$ & 20 & Cows & $\ldots 1$ \\
\hline
\end{tabular}

\section{Forage type not stated}

\section{Animal}

Animal trials conducted under controlled conditions have revealed the detrimental effects of heavily infested tall fescue forage. Average daily gains (ADG) of steers and calves grazing non-infested tall fescue pasture were 39 to $66 \%$ higher than animals grazing infested pasture (Table 1). Non-infested pastures have also had a positive influence on such performance parameters as beef gain per hectare (26 to $39 \%$ ), liveweight gain per head $(71 \%)$, feed intake $(55 \%)$ and milk production $(20 \%)$.

Since all of the trials reported in Table I were comparisons between $\mathrm{N}$ fertilised grass stands of infested vs non-infested tall fescue, it is difficult to assess the influence of mixtures of legumes and infested grass on animal performance. However, a two year Alabama study (Hoveland et al. 1981) indicated that a relatively small amount of legume in mixture can greatly enhance animal performance. An infested fescue sward containing $24 \%$ ladino clover increased beef gain/ha, average daily gain (ADG) and gain/head by 56,44 , and $51 \%$ respectively (compared with infested grass alone).

\section{Action plan for farmers}

Formal and informal surveys conducted in the southeastern U.S.A. have reported an infestation level of over $90 \%$ of the tall fescue pastures tested. Based on animal performance data collected to date it has been estimated that this problem annually costs farmers as much as \$U.S.360 million (Evans 1985).

Farmers can begin action by sampling suspected pastures for laboratory determination (aniline blue stain) of percent endophyte infestation. There are several state laboratories now accepting pasture samples for analysis. The Auburn University laboratory will accept samples from any state in the region.

Unfortunately no threshold level of infestation has yet been established to let farmers know at what level of infestation they should consider re-establishment of 
existing pasture swards. Limited data with steers suggests that for each $10 \%$ increase in infestation level, ADG is reduced by about $50.75 \mathrm{~g}$. Since cost of re-establishment is high (\$250.\$350 U.S./hectare) and pasture is often located on sloping, erodable land, farmers need to consider all the options. For new pasture establishment it is recommended that producers plant low-endophyte cultivars (seed tag indicated less than 5\% of seeds with endophyte) which are now available. Aged seed could be used provided it has been thoroughly tested to assure non-viable endophyte and that any decline in germination is compensated for by increasing the seeding rate accordingly. Since little or no low-endophyte KY 31 seed is currently available, new plantings of this variety would require aged seed.

\section{GUIDELINES FOR FARMERS}

1) Test for presence of the endophyte - several laboratories are available for testing in the region. Although no threshold level of infestation has been established, most states recommend complete re-establishment of pastures when test results indicate that more than $50 \%$ of the plants are infested with endophyte.

2) When establishing a new pasture use low-endophyte seed - low-endophyte cultivars are now available in the U.S.A. The seed tags should be labelled as $5 \%$ or less endophyte. Aged seed can be used if it is tested to assure non-viability and if seeding rate is adjusted accordingly. Pastures with the highest levels of infestation should be replanted first.

3) Renovations with legumes - pastures with low to moderate infestation levels $(<\mathrm{SO} \%)$ can be improved by planting white or red clover by minimum-till or no-till methods.

4) Use alternative grass species -since problems with infested tall fescue tend to be most severe during the hot summer months (when forage production is low), warm season pasture species should be established for summer grazing, i.e. bermudagrass, Cynodon dactalon L., sorghum-sudan hybrids, Sorghum bicolor Moench or pearlmillet, Pennisetum americanum.

5) Dairy cows should not be allowed to graze infested $(>10 \%)$ tall fescue. Evidence indicates milk production is severely affected by heavily infested tall fescue (serum prolactin levels are greatly depressed). In addition, the effects of grazing infected pasture seem to be residual suggesting that dry cows and heifers as well as the milking herd should avoid grazing infested tall fescue.

\section{SUMMARY COMMENTS}

The introduction of tall fescue into the transition zone of the U.S.A. almost 50 years ago has been of great benefit to the region. The large expansion of livestock industry in the region probably would not have been possible without the use of tall fescue. In fact, countless hectares have been saved from erosion due to the establishment of this long-lived, hardy grass. Nevertheless, the occurrence of animal disorders associated with the use of this grass has been known for over 30 years, and the causal agent(s) are only now beginning to emerge. The association between grasses and endophytic fungi has been known for many years, yet the tall fescue endophyte defied detection for at least 35 years. The lesson here for those involved in the development of "improved" forage species is that the developmental plan should include: a) an interdisciplinary team of scientists and b) intensive animal evaluation early in the developmental process.

Much is still to be learned about the complex interactions of plant, animal and endophyte involved in tall fescue toxicosis. Fortunately, a step in the right direction has been made that will ultimately allow tall fescue to contribute its full potential to animal production. 


\section{References}

Bacon, C.W.; Porter, J.K.; Robbins, J.D.; Luttrell, E.S. 1977. Appl. Environ. Microbiol. 34: 576.581. Ball, D.M. 1984. Auburn Veterinarian. 39: 66-70

Blaser, R.E.; Hammes, R.C.; Bryant, H.T.; Kimkaid, C.M.; Skrdla, W.H.; Taylor, T.H.; Griffith, W.L. 1956. Agron. J. 48: 508-513

Bush, L.; Buckner, R.C. 1973. In (A.G. Matches, ed.) Anti-quality components of forages. Crop Sci. Soc. Am. Spec. Publ. 4: 99-112.

Crejghton, N.C.; Garner, G.B. 1980. Fescue Foot. Univ. Missouri Ext. Ser. 2100

Evans, J.K. 1985. Proc, 41st Southern Pasture Forage Crop Imp. Conf. (in press)

Fergus, E.N.; Buckner, R.C. 1972. Crop Sci. 12: 714

Funk, C.R.; Halisky, D.M.; Johnson, M.C.; Siegel, M.R.; Stewart, A.V.; Ahmad, S.; Hurley, R.H.; Harvey, I.C. 1983. Bio/Technol. 1: 189.191.

Garrett, L.W.; Heiman. E.D.; Pfander, W.H.; Wilson, L.L. 1980. J. Anim Sci 51: 2371

Hoveland, C.S.; Haaland, R.L.; King C.C.Jnr; Anthony, W.B.; Clark, E.M.; McGuire, J.A.; Smith, LA.; Grimes, H.W.; Holliman, J.L. 1980. Agron. J. 72: 1064.1065.

Hoveland, C.S.; Harris, R.R.; Thomas, E.E.; Clark, E.M.; McGuire, J.A., Easton, d.T.; Ruf, M.E. 1981 Alabama Agric. Exp. Sta. Bul. 530.

Hoveland, C.S.: Schmidt, S.P.; King, C.C.Jnr.; Odom, J.W.; Clark, E.M.; McGuire, J.A.; Smith, L.A. Grimes, H.W.; Holliman, J.L. 1983. Agron. J. 75: 821-824.

Hurley, W.L.; Convey, E.M.; Leuna, K.; Edgerton, L.A.; Hemken, R.W. 1981. J. Anim. Sci. 51: 374. King, C.C.Jnr; Hoveland, C.S.; Schmidt, S.P.; Clark, E.M.; McGuire, J.A.; Smith, L.A.; Pedersen, J.F.; Grimes, H.W.; Holliman, J.L. 1982. Agron. Abstr. Anaheim, Calif., P.149.

Lyons, P.C.; Bacon, C.W. 1984. Phytopathology 74: 792.

Neil, J.C. 1941. N.Z. J. Sci. Tech. 23: 185

Porter, J.K.; Bacon, C.W.; Robbins, J.D. 1979. J. Agric. Food Chem. 27: 595-598

Prestidge, R.A.; Pottinger, R.P.; Barker, G.M. 1982. Proc. 35th N.Z. Weed Pest Cont. Conf: 119.122

Robbins, J.D. 1983. Proc. Toll Fescue forage workshop, Atlanta, GA: 1-4.

Rumsey, T.S.; Stuedeman, J.A.; Wilkinson, S.R.; Williams, D.J. 1979. J. Anim. Sci. 48: 673

Schmidt, S.P.; Hoveland, C.S.; Clark, E.M.; Davis, M.D.; Smith, L.A.; Grimes, H.W.; Holliman, J.L. 1981. Ibid 55: 1259-1263.

Siegel, M.R.; Varney, D.R.; Johnson, M.C.; Nesmith, W.C.; Buckner, R.C.; Bush, L.P.; Burrus, P.B.; Hardison, JR 1984. Phytopathology 74: 937-971.

Siegel, M.R.; Latch, C.M.; Johnson, M.C. 1985. Plant Disease 69: 179.183. 